\title{
Efektivitas Edukasi SADARI (Pemeriksaan Payudara Sendiri) Untuk Deteksi Dini Kanker Payudara
}

\author{
Jajuk Kusumawaty, Elis Noviati, Ima Sukmawati, Yanti Srinayanti, Yuyun Rahayu \\ STIKes Muhammadiyah Ciamis \\ Email: jajukkusumawaty@gmail.com, 082240935050
}

\begin{abstract}
Abstrak
Kanker payudara disebut juga carcinoma mamae adalah suatu jenis kanker yang tumbuh dalam kelenjar susu, jaringan lemak, maupun pada jaringan ikat payudara. Jumlah penderita kanker payudara lebih banyak (sekitar 90\%) dibandingkan dengan penderita keganasan pada payudara. Pada Pengabdian Masyarakat ini, seluruh siswi SMA di Kabupaten Ciamis, Jawa Barat menjadi mitra pengabdian, tujuan kegiatan ini adalah untuk meningkatkan pengetahuan siswi SMA tentang SADARI sehingga terdeteksinya kanker payudara secara dini dan menurunkan prevalensi terjadinya kanker payudara di wilayah Kabupaten Ciamis. Metode yang dipakai dalam kegiatan ini ada tiga tahapan yang dilakukan pada kegiatan pengabdian masyarakat, tahapan pertama dilakukan untuk mengetahui wawasan mitra tentang SADARI, dilakukan survey permulaan dengan menggunakan kuesioner, tahapan kedua adalah pendidikan kesehatan tentang SADARI melalui zoom meeting, tahap ketiga adalah evaluasi tentang pemahaman SADARI setelah demonstrasi penayangan video, evaluasi dilakukan dengan menggunakan kuesioner. Hasil dari survey menunjukan Pre Test dengan hasil rata-rata 8,87 sedangkan Post Test nilai rata- ratanya 10,00. Nilai signifikan tailed 0,00 hasilnya $<0,05$ artinya Ho di Tolak dan Ha di Terima, artinya adanya perbedaan rata-rata hasil Pre Test dengan Hasil Post Test sehingga adanya pengaruh Edukasi Webinar SADARI untuk remaja dalam meningkatkan pengetahuannya. Peserta sudah memahami makna pentingnya SADARI namun masih memerlukan tambahan sosialisasi dan motivasi terkait pentingnya pemeriksaan payudara sendiri secara berkala untuk deteksi dini kanker payudara.
\end{abstract}

Kata kunci: Agregat, remaja, SADARI

\begin{abstract}
Breast cancer is also called the carcinoma of mamae is a cancerous ienis that grow in mammamae, both fat and mammary tissues. The number of people with cancer. Breasts.More (about 90\%) than those with ferocity in the community's service, all high school students in ciamis district, west Java become service partners, the goal is to improve high school students' knowledge of knowingly and to develop breast cancer early and to lower the prevalence of breast cancer in ciamis county. The method used in this activity involves three stages of community devotiondilakuThe first stage is to know the partner's insights masyaraka On conscious, a preliminary survey using a questionnaire, the second stage is education in health care through realisationl zoom meeting, phase three is about evaluation Conscious understanding after the video presentation demonstration, the evaluation was made using emanaeQuestionnaire. The results from the survey showed a pre-test with an average of 8.87 , while the average value test was 1000 . The significant value of the $0 . k .00$ result would mean that ho was declined and ha received would mean an average pretest difference with a post test so that the education education would be too happy for a teenager to increase his knowledge. Attendees already understand the significance of importance but still require additional socialization and motivation, the importance of daily breast exam of keyword breast cancer: aggregate, youth, realize
\end{abstract}

Keywords: Aggregate, Youth, SADARI 


\section{PENDAHULUAN}

Kanker payudara disebut juga carcinoma mamae adalah suatu jenis kanker yang dapat menyerang siapa saja baik kaum wanita maupun pria. Kanker payudara ini tumbuh dalam kelenjar susu, jaringan lemak, maupun pada jaringan ikat payudara. Hingga kini kanker payudara masih menjadi hal yang menakutkan terutama pada kaum wanita, karena kanker payudara ini diidentikkan dengan sebuah keganasan yang dapat berakibat pada kematian. Tingkat bahaya keganasan dan kanker pada payudara sama saja. Hanya saja, jumlah penderita kanker payudara lebih banyak (sekitar 90\%) dibandingkan dengan penderita keganasan pada payudara . (Kusumawaty et al., 2020)

Berdasarkan WHO, kanker payudara adalah kanker yang paling sering terjadi pada wanita, berdampak pada 2,1 juta wanita setiap tahunnya, dan menyebabkan jumlah terbesar kematian akibat kanker payudara. Pada tahun 2018, diperkirakan 627.000 wanita meninggal karena kanker payudara, yaitu sekitar $15 \%$ dari semua kematian akibat kanker di kalangan wanita (WHO, 2018). Kanker Payudara di Indonesia merupakan angka kejadian untuk perempuan yang tertinggi. Kanker payudara berdasarkan WHO adalah kanker yang paling sering terjadi di kalangan wanita. Pada Tahun 2018 diperkirakan sebesar 42,1 per 100.000 penduduk dengan rata-rata kematian 17 per 100.000 penduduk. (Kemenkes RI, 2016)

Salah satu faktor tingginya angka kejadian adalah kurangnya edukasi kanker payudara sejak remaja dalam mendeteksi dan menangani kanker payudara secara dini. Angka kematian yang tinggi akibat kanker ini juga terjadi karena pasien yang datang ke tempat pelayanan kesehatan sudah berada dalam stadium lanjut. Jika pasien telah berada dalam kanker stadium lanjut, maka proses penyembuhannya akan sulit untuk dilaksanakan. Kurangnya pengetahuan masyarakat mengenai kanker dan bagaimana cara mendeteksi merupakan salah satu penyebab angka kematian kanker payudara yang tinggi. (Heryani, Kusumawaty, Gunawan, \& Samrotul, 2020)

Pemerintah telah memiliki sejumlah kebijakan dan program pengendalian dari kanker payudara ini. Program ini bertujuan untuk meningkatkan deteksi dini, penemuan dan tindak lanjut dini kanker, meningkatkan kualitas hidup penderita kanker, dan menurunkan angka kematian akibat kanker. Untuk mencapai tujuan tersebut, dilaksanakan program pengendalian kanker yang meliputi upaya promotif dan preventif dengan meningkatkan pengetahuan masyarakat akan kanker payudara dan deteksi dini kanker. Program utama pada kanker payudara adalah periksa payudara sendiri (SADARI) dan Periksa Payudar Klinis (SADANIS) (Kemenkes RI, 2017)

Kegiatan pengabdian ini bertujuan sebagai upaya deteksi kanker payudara sedini mungkin, menambah pengetahuan remaja, menurunkan prevalensi kanker payudara di wilayah Kabupaten Ciamis. Upaya penyuluhan kesehatan untuk pengubah pengetahuan, sikap dan perilaku akan lebih efektif dilakukan terhadap kelompok umur remaja dibandingkan dilakukan pada kelompok umur dewasa. Upaya penyuluhan tersebut dilakukan dengan menggunakan alat bantu yang dapat menarik perhatian sasaran. Salah satu alat media tersebut adalah leaflet. Leaflet adalah selembar kertas yang dapat dilipat sedemikian rupa, berisi tulisan dan gambar, yang tercetak berisi tentang suatu masalah khusus untuk sasaran dan tujuan tertentu. Leaflet sebagai media visual dapat memperlancar pemahaman dan memperkuat ingatan, serta mudah dan praktik untuk dibawa kemanapun. Visual dapat meningkatkan minat para remaja dalam memahami isi materi. (Heryani et al., 2020)

\section{BAHAN DAN METODE}

Mitra Pengabdian kepada Masyarakat (PKM) ini adalah seluruh siswi SMA di Kabupaten Ciamis. Keseluruhan peserta diikuti oleh para remaja karena masa remaja adalah masa peralihan atau masa transisi dari anak menuju masa dewasa. Pada masa ini begitu pesat mengalami pertumbuhan dan perkembangan baik itu fisik maupun mental. Kanker payudara adalah kanker yang paling sering terjadi pada wanita dan kurangnya pengetahuan masyarakat mengenai kanker serta bagaimana cara mendeteksi merupakan salah satu 
penyebab angka kematian kanker payudara yang tinggi. Maka usia remaja perlu untuk melakukan SADARI secara rutin sebagai upaya pencegahan dan deteksi dini. Sehingga wanita perlu diberikan informasi mengenai SADARI sejak usia remaja agar terbiasa melakukannya.

Metode yang dipakai dalam kegiatan ini ada tiga tahapan yang dilakukan pada kegiatan pengabdian masyarakat :

1. Tahapan pertama dilakukan untuk mengetahui wawasan mitra tentang SADARI, dilakukan survey permulaan dengan pengisian pre test menggunakan kuesioner.

2. Tahapan kedua adalah pendidikan kesehatan tentang SADARI melalui zoom meeting.

3. Tahap ketiga adalah evaluasi tentang pemahaman SADARI setelah demonstrasi penayangan video, evaluasi dilakukan dengan pengisian post test menggunakan kuesioner.

\section{HASIL}

Hasil survey webinar diikuti oleh 53 peserta dengan menggunakan kuisioner pre test dan post test. Kuisioner yang telah terisi kemudian di analisis untuk mengetahui tingkat pengetahuan siswi tentang SADARI sebelum dan sesudah mengikuti kegiatan pengabdian masyarakat. Dari hasil analisis menunjukan Pre Test dengan hasil rata-rata 8,87 sedangkan Post Test nilai rata- ratanya 10,00 . Nilai signifikan tailed 0,00 hasilnya $<0,05$ artinya Ho di Tolak dan Ha di Terima, artinya adanya perbedaan rata-rata hasil Pre Test dengan Hasil Post Test sehingga adanya pengaruh Edukasi Webinar SADARI untuk remaja dalam meningkatkan pengetahuannya.

\section{PEMBAHASAN}

Pada awal diskusi, peserta diajak untuk mengidentifikasi kemungkinan terjadinya resiko kanker payudara dengan enam langkah pemeriksaan payudara sendiri. Selain itu juga peserta terlebih dahulu diberikan pemahaman mengenai agregat remaja, karena remaja merupakan kelompok rentan terkena kanker payudara. SADARI perlu dilakukan karena seiring berjalannya waktu, penyakit ini mulai mengarah ke usia lebih muda. Respon baik secara fisik maupun psikis peserta terhadap langkah-langkah pemeriksaan payudara sendiri serta pemahaman mengenai kanker payudara dan kesehatan reproduksi, menganalisis apakah respon peserta tersebut sudah tepat atau kurang tepat, dan memberikan pemahaman bagaimana seharusnya peserta menyikapi jika terdapat benjolan pada payudara. Gambar 2 Dimana diskusi berlangsung menarik dan interaktif, peserta sangat antusias dan menginginkan pelatihan kembali melalui webinar, menyarankan agar kegiatan seperti ini diselenggarakan secara terus menerus dan ditingkatkan menjadi lebih baik lagi. Pada saat pandemi seperti ini peserta memang sangat membutuhkan sekali kegiatan bermanfaat seperti ini. (Neli Sunarni, Yanti Srinayanti , Ade Fitriani, 2020)

Dari hasil survei melalui kuesioner bisa di lihat di tabel 1 diperoleh informasi bahwa kegiatan efektifitas edukasi pemeriksaan payudara sendiri (SADARI) untuk deteksi dini kanker payudara ini membawa perubahan yang signifikan pada pengetahuan kesehatan peserta. Selain itu, peserta juga mengharapkan adanya kelanjutan kegiatan secara offline. Adapun materi yang membuat pengetahuan peserta bertambah adalah sebagai berikut : menambah pengetahuan peserta tentang arti remaja sebenarnya, pengetahuan tentang kesehatan reproduksi pada remaja, pembahasan kanker payudara, dan demonstrasi langkah-langkah pemeriksaan payudara sendiri melalui penayangan video serta peserta diberikan penjelasan mengenai dampak dari SADARI itu sendiri.

Penayangan video langkah-langkah SADARI kepada seluruh peserta dilakukan agar peserta dapat lebih memahami dan menjadi pengingat karena pada umumnya pembelajaran secara visual akan lebih diingat. Selain itu juga peserta diberikan motivasi agar selalu rutin mempraktekannya sendiri serta jika ditemukan benjolan atau ketidaknormalan untuk tidak sungkan melakukan pemeriksaan berlanjut. 


\section{KESIMPULAN DAN SARAN}

Kegiatan Pengabdian kepada Masyarakat tentang edukasi SADARI untuk meningkatkan pengetahuan siswi SMA di Kabupaten Ciamis telah dilaksanakan dan mendapat sambutan yang baik dari peserta. Setelah mengikuti kegiatan didapatkan hasil analisis menunjukan Pre Test dengan hasil rata-rata 8,87 sedangkan Post Test nilai rataratanya 10,00 . Nilai signifikan tailed 0,00 hasilnya $<0,05$ artinya Ho di Tolak dan Ha di Terima, artinya adanya perbedaan rata-rata hasil Pre Test dengan Hasil Post Test sehingga adanya pengaruh Edukasi Webinar SADARI untuk remaja dalam meningkatkan pengetahuan.

\section{UCAPAN TERIMA KASIH}

Penulis mengucapkan terima kasih setinggi tingginya kepada STIKes Muhammadiyah Ciamis yang telah memberikan dukungan untuk terselenggaranya kegiatan ini melalui lembaga Penelitian dan Pengabdian Kepada Masyarakat (LPPM), selain itu penghargaan di berikan kepada seluruh siswi di kabupaten ciamis yang bersedia menjadi mitra kegiatan ini.

\section{DAFTAR PUSTAKA}

Heryani, H., Kusumawaty, J., Gunawan, A., \& Samrotul, D. (2020). Efektivitas Leaflet terhadap Peningkatan Keterampilan tentang Pemeriksaan Payudara Sendiri (SADARI) pada Remaja Putri di Pondok Pesantren Ar-Risalah Kabupaten Ciamis. Jurnal IImu Dan Teknologi Kesehatan. https://doi.org/10.33666/jitk.v11i1.237

Kusumawaty, J., Gunawan, A., Supriadi, D., Heryani, H., Lismayanti, L., \& Milah, D. S. (2020). Effectiveness of Health Education With Media Leaflet on Knowledge and Attitude of Self-Breast Examination in Young Woman. 27(ICoSHEET 2019), 334-336. https://doi.org/10.2991/ahsr.k.200723.084

Neli Sunarni, Yanti Srinayanti , Ade Fitriani, R. S. (2020). Pengetahuan dan Penatalaksanaan SADARI pada Mahasiswi Prodi S1 Keperawatan STIKES Muhammadiyah Ciamis. Tunas-Tunas Riset Kesehatan, 10, 38-41.

Kemenkes , R. (2016). Program Pengendalian HIV AIDS dan PIMS di Fasilitas Kesehatan Tingkat Pertama: Petunjuk Teknis di Rektorat Jendral Pencegahan dan Pengendalian Penyakit. Indonesia: Kemenkes RI.

Kemenkes, R. (2017). Profil Kesehatan Indonesia. Indonesia: Kemenkes RI. 


\section{LAMPIRAN}

Tabel 1. Descripsi PreTest dan PostTes

\begin{tabular}{|r|l|r|r|r|r|r|}
\hline No & Kegiatan & N & Min & Max & M & $\begin{array}{c}\text { Std.Devalatio } \\
\mathrm{n}\end{array}$ \\
\hline 1. & Pre Test & 53 & 7 & 9 & 8.89 & .423 \\
\hline 2. & Post Test & 53 & 10 & 10 & 10.00 & .000 \\
\hline 3. & N(listwise) & 53 & & & & \\
\hline
\end{tabular}

Tabel 1. Paired Sample Test

\begin{tabular}{|c|c|c|c|c|c|c|c|c|c|}
\hline & & \multicolumn{5}{|c|}{ Paired Differences } & \multirow[b]{3}{*}{$\mathrm{t}$} & \multirow[b]{3}{*}{ df } & \multirow{3}{*}{$\begin{array}{l}\text { Sig. }(2- \\
\text { tailed) }\end{array}$} \\
\hline & & \multirow[b]{2}{*}{ Mean } & \multirow[b]{2}{*}{ Std. Deviation } & \multirow{2}{*}{$\begin{array}{c}\text { Std. Error } \\
\text { Mean }\end{array}$} & \multicolumn{2}{|c|}{$\begin{array}{c}95 \% \text { Confidence Interval } \\
\text { of the Difference }\end{array}$} & & & \\
\hline & & & & & Lower & Upper & & & \\
\hline Pair 1 & Pre Test - Pro Test & -1.130 & .436 & .059 & -1.249 & -1.011 & -19.023 & 53 & .000 \\
\hline
\end{tabular}

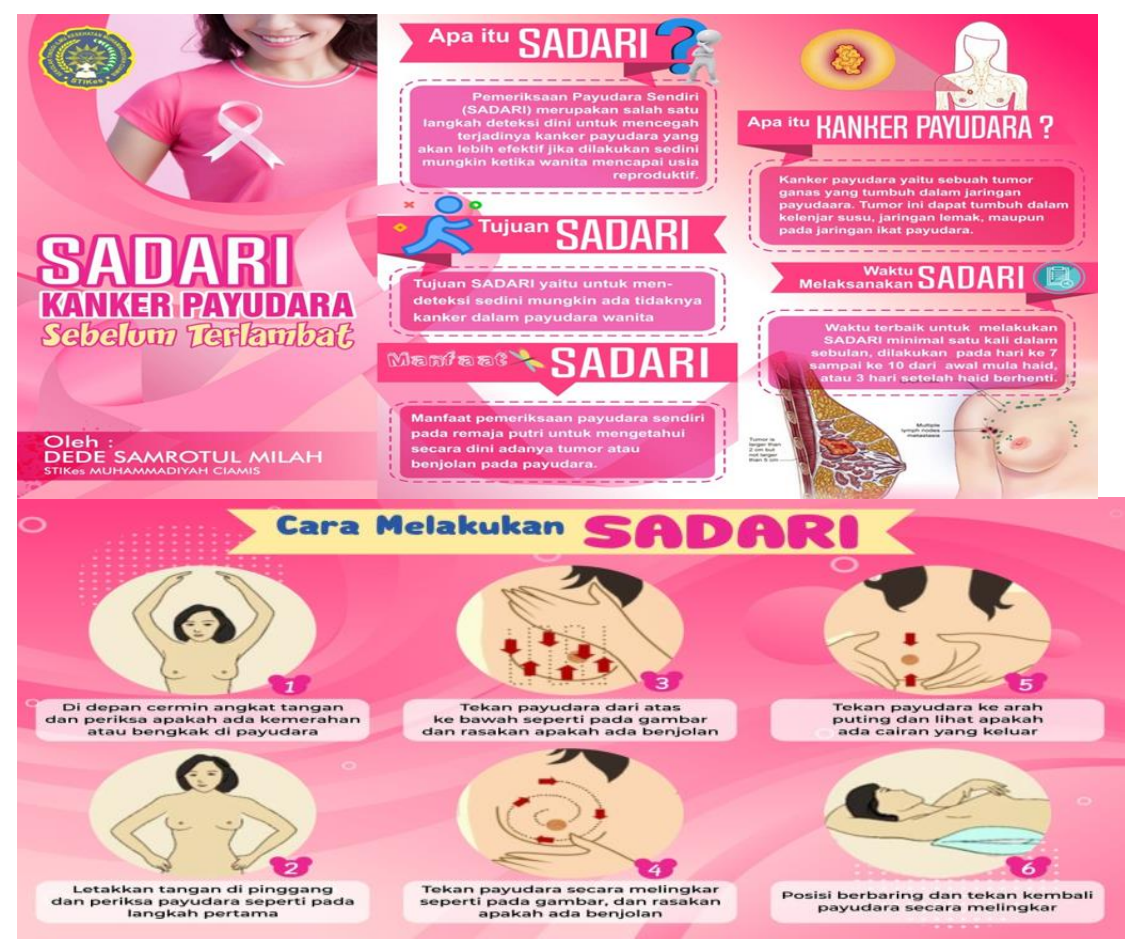

Gambar 1. Leaflet SADARI (Heryani et al., 2020)
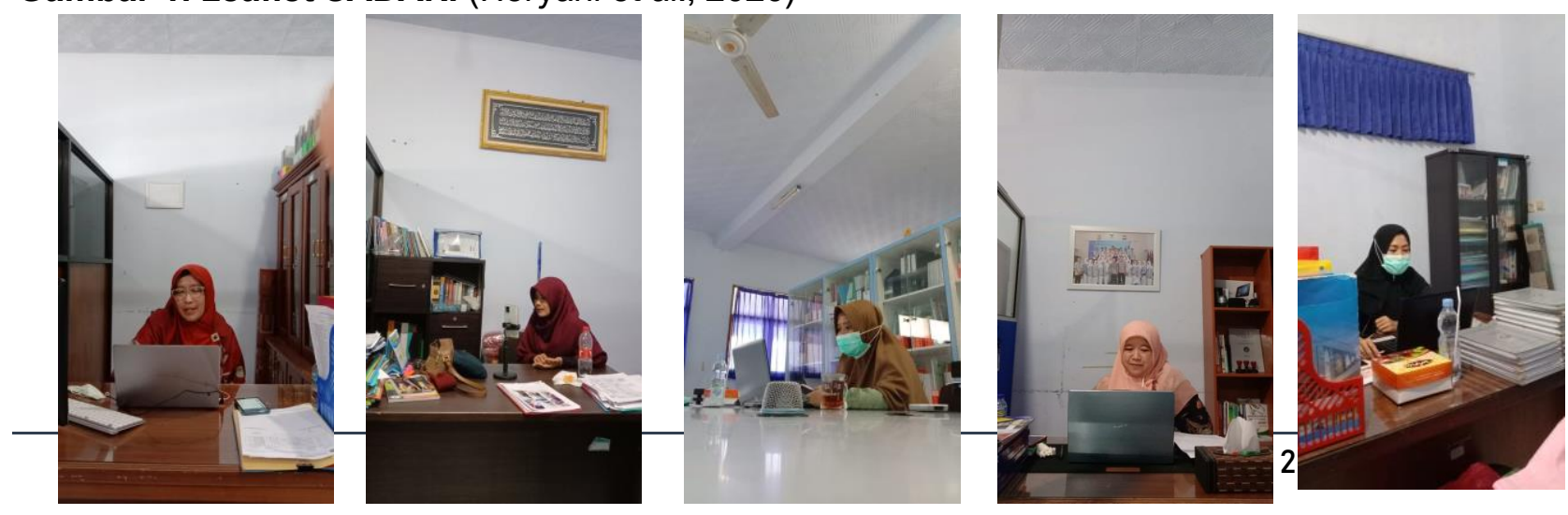
Gambar 2. Dokumentasi Pemateri

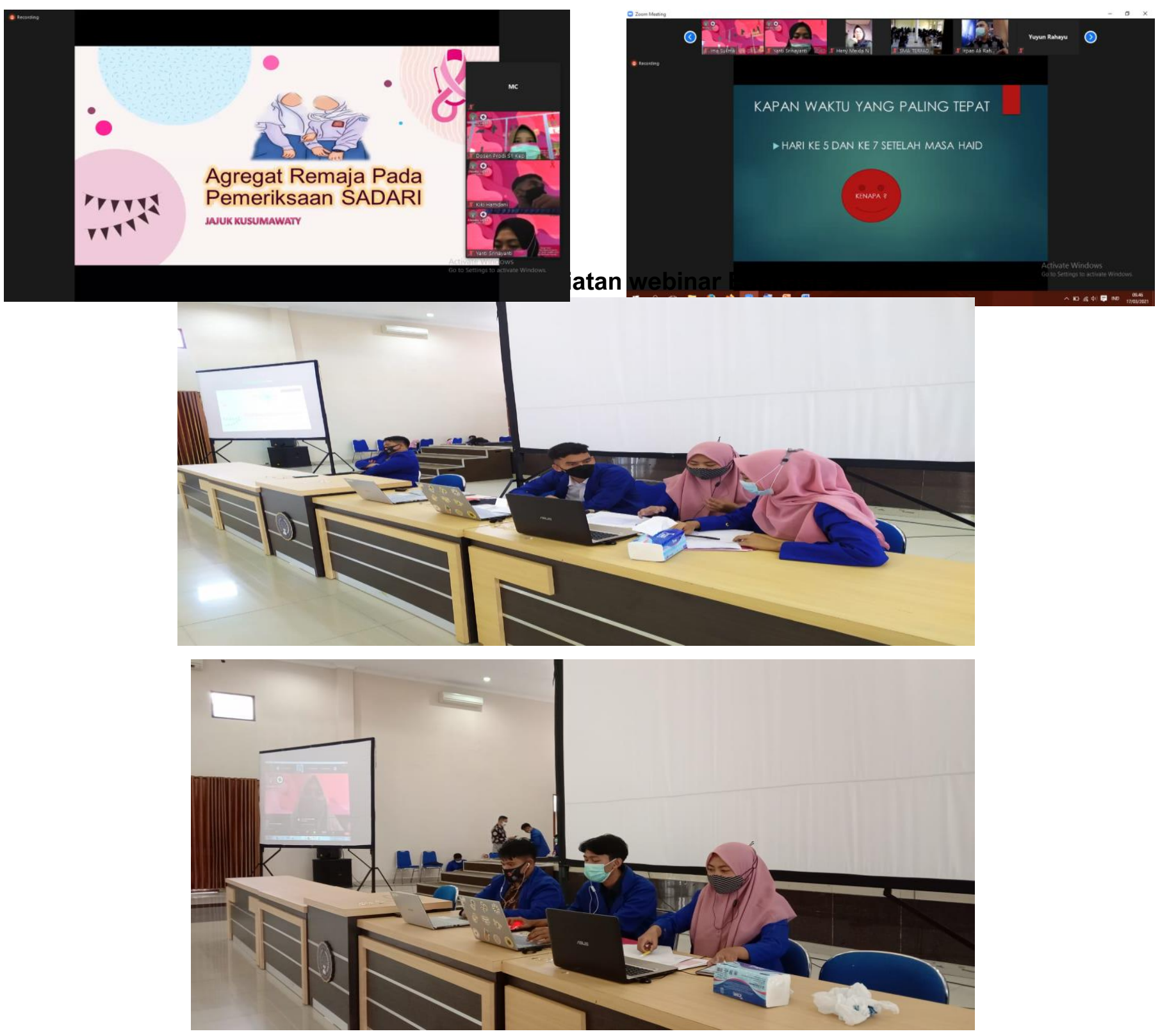

